The Third Pole: Journal of Geography

Vol. 18 - 19: 55-70, 2019

DOI: https://doi.org/10.3126/ttp.v18i0.28007

Department of Geography Education,

Central Department of Education, T.U., Kathmandu, Nepal

\title{
LAND USE AND LAND COVER CHANGES IN TANKHUWAKHOLA WATERSHED, EASTERN HILLS NEPAL
}

\begin{abstract}
Shambhu Prasad Khatiwada, PhD $^{1}$
Abstract

This paper examines land use and land cover changes in the eastern hills in general and Tankhuwakhola watershed in particular. More specifically, it attempts to analyze the spatial pattern of land use and land cover changes in the Tankhuwakhola watershed. Land is an integral part of the local community addressing conservation of water, biodiversity resources, and agricultural activities for improving local livelihoods through diversified activities. Land use can be considered as to reflect the degree of human activities directly related to land and making use of its resources and land cover is defined as the observed bio-physical cover of the watershed. The local communities are involved in land used in various ways, ranging from agriculture, forestry, settlements, and water bodies and so on. It shows that land use and land cover change comprises multidisciplinary in nature. This paper concludes that changes in land cover may reveal a response to a shift in local climatic conditions, increasing assess to road transportation, market integration and adoption of new agricultural crops. For this purpose, the data are collected from different sources, including satellite image and topo-sheet maps.
\end{abstract}

Key words: Land cover, livelihoods, biophysical conditions, market integration, satellite image

\section{Introduction}

FAO (1984) defines land as something that includes all features of the natural event which can influence its use by man; not only landforms and soils, but also climate and vegetation, including existing forest (p. 2) while the HMG of Nepal (1964) defines "land-use means the process of making use of land divided into different regions in

1 Dr. Khatiwada is a Professor, Department of Geography Education, Central Department of Education, Tribhuvan University,Email: shambhukhatiwada@yahoo.com 
various ways according to the utilization of the land (p. 4)". The local land resource had changed into the economic and social structure by the clearance of forest that drove new utilization for different purpose known as land use. Land use and land cover change promote the transition to more sustainable production systems and practices in the crop, livestock, forestry, and fisheries sector. The term 'land' cover refers to the physical surface characteristics of land and it is directly observable. On the other hand, land use describes the economic and social functions of land, or the purposes for which humans exploit land cover. FAO and UNEP (1999) define land use as the "total of arrangement, activities and inputs that people undertake in a certain land-cover type". The land cover and land use are interrelated to each other, but these linkages are complex. A single type of land cover, perhaps grassland, may support many uses, such as livestock production or recreation, while a single use, say nature conservationists, may take on a number of different cover types.

Turner et al. (1995) analyzed the systemic changes in land use and land cover in relation to biophysical conditions and human activities of a particular area. Ellis (2007), and Lambin et al. (1999) have also concluded that the drivers for the changes in land use and land cover associated with biophysical attributes of the earth's surface and humanmodification. However, the extent of land use has not to uniform over geographic space. It varies from one place to another depending on the nature and stage of societies, such as a tribal, traditional and developed stage. For example, human activities have dramatically transformed the Rockies, at least since Euro-American settlement in the mid to late 1800s (Travis, Theobald, \& Fagre, 2002). The presence of man has greatly been affected by the physical environment of a place in which society is settled down there. The society has brought new land permanently by the clearance of forest, carving terraces on the hill slopes and use of technologies for transforming stock and flow of resources. As a result, the effects of human uses of lands have made a complex layer of use belts in several places. For example, Malla \& Shrestha (1983) made rationality of land uses in different parts of Nepal and explained that agricultural land down in river valleys and lower slopes, settlements are further up and finally in the upper parts forest zones, pastures and meadows (p. 18).

Allan (1986) concludes that the advent of road, track, and bridge construction, especially in the Alpine region of Europe, have radical changes in land use. These changes are functionally related to the degree of accessibility between mountains and lowland areas. It reflects successful human manipulation of the great range in environmental conditions found in mountain habitats. Virgo \& Subba (1994) have pointed out some of the factors influencing in land use changes which were active fallowing of land, efforts by the extension services, farmers response to changing markets, and improved accessibility 
due to construction of Dharan-Dhankuta-Basantapur road in Dhankuta district between 1978 and 1990. Bencherifa (1988) argues that mountain environment are better endowed in terms of effective resources than the surrounding lowlands. In this environment, local communities have intensively used the soils, such as multiple cropping, varieties of trees and crops, association of cattle raising in an intensive system, and altitudinal biotype used for agro-pastoralism in Altai Mountains of Morocco.

Land has become an integral part of the way of living of the Nepalese people where agriculture is a mainstay for the majority of people (Sharma, 1978). The contribution of agricultural sector (agriculture, forest and fisheries) in Nepalese total Gross Domestic Product is about 27.6 percent in the FY 2017/18 and it was 38.8 percent in the FY 2010/11 (MoF, 2018). It provides more than 65.6 percent employment opportunities in 2011(MoAD, 2013). But the land does not appear to be evenly distributed in all regions of Nepal. It varies according to their quantity, quality, and distribution. The arable land in the hills and mountains appear to be much tiny than that of the Tarai. The people who lived in the hills and mountains have used the same amount of land available in the local area for various purposes. For example, agriculture, settlements, roads, pastures, forest, aesthetics and so on. In this limited land, government offices, development works, and government policies also make a difference in land use. The land-use system has more prevailed under customary land rights (Kipat system) in the eastern hills of Nepal. Two incidents, such as the land reform program (1966) and cadastral mapping system (1972) have considered land-use and land cover change in this area (Shrestha, 1995).

The Tankhuwakhola watershed area seems to have been inhabited by the Kirati community since ancient times. They had yielded evidence of agro-pastoral civilization before the arrival of Limbu tribes around 1800 AD (Shrestha, 1995). Their slashes and burn technology had relatively little effect on the utilization of watershed resources. The integration of this territory into Gorkha state changed the political and administrative roles of the watershed area, introduction of Party-less Panchayat political system, extension of district offices and lower level service center demands the land for different purposes. The expansion of the Koshi highway and its link roads have further sprawled new economic opportunities, increasing in the larger cities outside the hills. The urbanization and market integration have also opened up new land-based income opportunities in the watershed (Virgo \& Subba, 1994, Khatiwada, 2014). As a result, most of the communities who rooted in this watershed over centuries have changed their traditional farming systems into more profitable crops. The results of the various studies have highlighted that biophysical factor as the driver as compared to socioeconomic forces (Turner et al., 1995; Ellis, 2007; \& Lambin et al., 1999). But human activities have also exerted pressure to drive on land-use changes in the mountain areas (Price, 
Byers, Friend, Kohler \& Price, 2013). In this context, it is necessary to have a rigorous study to answer the following unrevealed questions regarding the past 20 years of land use and land cover change. What factors contribute to the change in land use and land cover? How has this change associated with the human activities and socioeconomic development of the watershed area? This paper attempts to answer these questions by the case of Tankhuwakhola watershed area, eastern hills of Nepal.

\section{Methods and Materials}

\section{Study Area and Data Sources}

Study area. The study area lies in the Tankhuwakhola watershed on the eastern hills of Nepal and southern slope of the Tinjure-Milke Mountain Range. The area comprises of a hilly terrain of remarkable grander with metamorphic and sedimentary rocks. The steep and rugged topography makes more than 95 percent area of the hill-slope. The study area is made with the distinctive topographic features, such as Lekh, Kachhad, and Basi and comprises the narrow river valley, undulating hill slopes with flat upland terraces (Tars) and steep slope. Tankhuwakhola watershed has extended from $27^{\circ} 59^{\prime}$ to $28^{\circ} 5^{\prime} 10^{\prime \prime}$ Northern latitude and longitudinal extension of $83^{\circ} 41^{\prime} 45^{\prime \prime}$ to $83^{\circ} 52^{\prime} 14^{\prime \prime E}$ (Fig.1). The watershed area has been surrounded by Jorpati-Guranse-Trisule in the north, JorpatiTankhuwa-Sibhuwadanda in the east, Hile-Dhankuta-Chulibandanda in the west, and Tamar River in the south. This watershed has covered an area of 73.93 sq.km by the 50 percent areas of Dhankuta Municipality and about 25 percent of Chhathar-Jorpati Gaunpalika. The latest population enumerated of this watershed was 25583 in 2011 (CBS, 2014). There were 10984 (42.9\%) male and 14599 (57.1\%) female and with 4.2 average family sizes.

The Tankhuwakhola watershed lies in the warm temperate climatic zone. It is characterized by warm and humid weather even in summer. The mean maximum temperature ranges between $21.8^{\circ} \mathrm{C}$ to $33.64^{\circ} \mathrm{C}$ and winter temperature $8.08^{\circ} \mathrm{C}$ in January in the year of 2018. The watershed has been receiving rainfall from the onset of the south-west monsoon in the summer season. The average rainfall varies from $9.4 \mathrm{~mm}$ in December and $5240.9 \mathrm{~mm}$ in June. Decreasing air temperature usually coincides with increasing elevation, which directly influences the length of growing season at different elevation zones. Each elevation zone has a commonly distinguished different types of climate such as temperature and precipitation.

Owing to the weather conditions, cultivation activities were limited to a single or multiple crops in a year. It has made mixed type of sub-tropical evergreen forest rich. Vegetation species vary with increasing altitude such as below 1000 meters, mostly 
consist of deciduous forest. The main species are as Sal (shorearobusta), Jamuna (syzygium cumini), Khayar (acacia catechu), Karma (Adina cordifolia) and mixed species, whereas the upper sub-tropical species consists of Chilaune (schima wallichi), Uttis (alnus nepalnesis), Katus (lithocarpus pachylla) and Sallo (pinus roxburgii) and various bamboos (garmineae family).

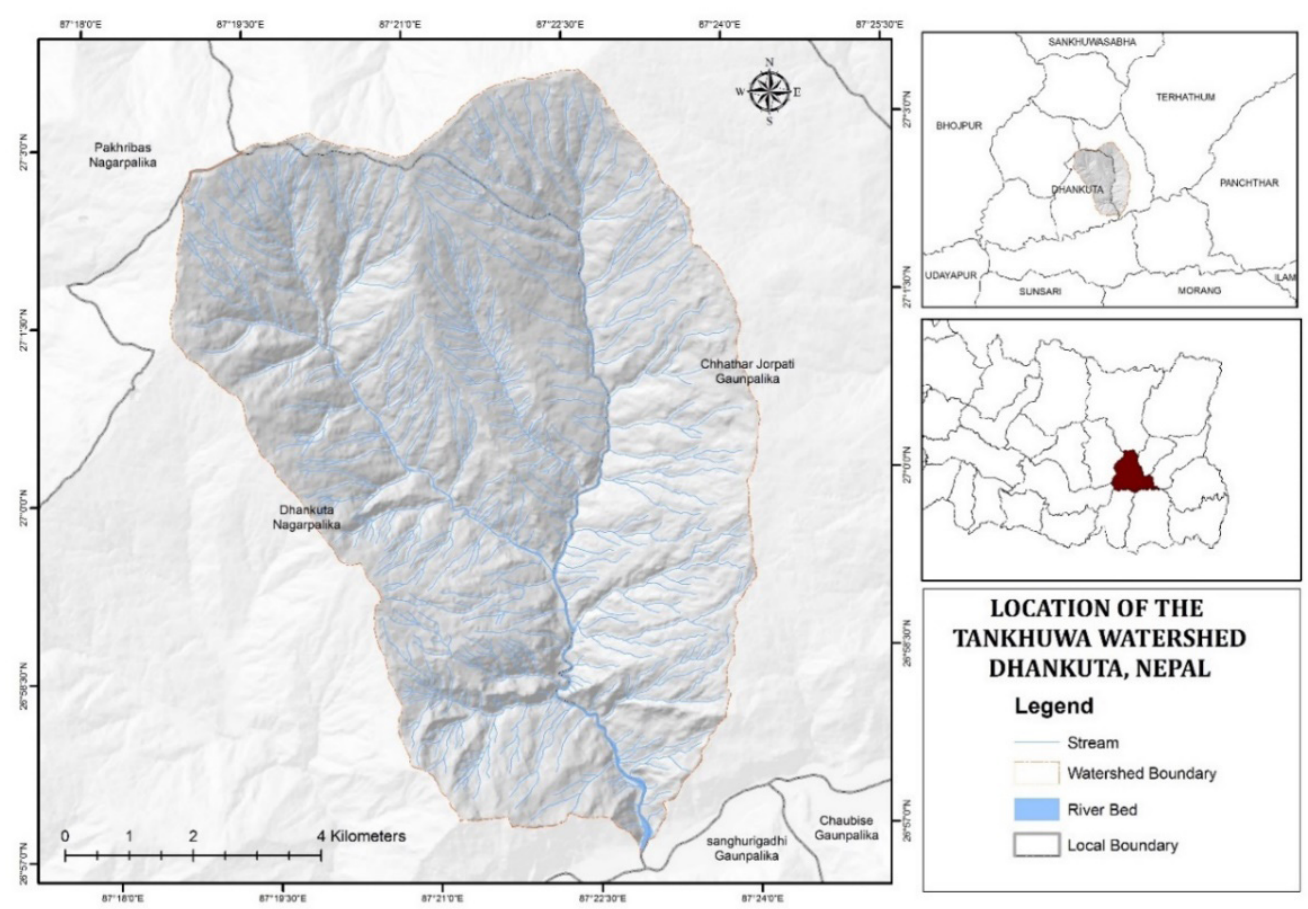

Figure 1: Location map

Data sources and methods. This paper is mainly based on both primary and secondary data sources. Primary data were generated from Geo-information technologies such as satellite imageries (WorldView-02), field verification and visual interpretation and multi criteria land use classification evaluation (MCE) method and participatory process i.e. FGD, interactions, Key Informant Interviews. Secondary data were collected from topographical maps, digital data, and LRMP reports. Geographic Information System (GIS) and Remote Sensing (RS) is a computer system used to allow visualizing, manipulating, capturing, and storage of data at different scales. A topographical data layer has also used to delineate administrative boundaries, contour, hydrology and other forms of land use and land cover on the scale of $(1: 25,000)$. These data were obtained from the official records of the Survey Department of Nepal. Geographic Information 
System (GIS) and digital elevation model (DEM) were commonly used to represent the surface (topography) of this watershed. Socioeconomic and climatic data were also collected from the DDC and VDC profiles. The data are captured by Geo/earth science technologies (GIS and RS). Both analytical and field data gathering methods were used for data analysis. For example, decadal land use and land cover change matrix have been prepared by images superimposition at different time intervals.

\section{Results and Discussions}

Present land use patterns. Tankhuwakhola is a landscape which contains a mosaic of ecosystems, including human-dominated ecosystems. The watershed can be described as cultural landscape where local communities developed different layering of ecosystems that occur at different elevations due to varying environmental conditions. Temperature, humidity, soils and solar radiation are important factors in determining altitudinal and vegetation zones which consequently support land use and land cover changes. The growth of population has increased pressures on the lands. Because, the stock of land resources in the watershed is only $73.93 \mathrm{sq} . \mathrm{km}$ and that flow for different uses. The local communities of the Tankhuwakhola watershed area are the users of the land available there. They have used the land for different purposes regarding food production, dwelling, recreation, material processing and so on. This paper reveals that the present land use patterns which are allocated for different uses for a span of time. For this purpose, a decadal change matrix in the year's of1990, 2000 and 2010 has prepared for the comparative study of land use and land cover changes in the watershed (Table 1, 2 and 3). And it is transferred into GIS software to prepare land use maps (Fig. 2,3, and 4).

Table-1: Decadal land use and land cover change matrix analysis (1990 to 2000)

\begin{tabular}{|c|c|c|c|c|c|c|c|}
\hline \multirow{2}{*}{ Year } & \multirow{2}{*}{$\begin{array}{l}\text { Land use \& } \\
\text { Land Cover }\end{array}$} & \multicolumn{6}{|c|}{2000 (Area Sq. km.) } \\
\hline & & Agriculture & Forest & Bush & Grass & Barren & Total \\
\hline \multirow{6}{*}{ 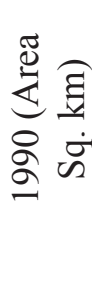 } & Agriculture & 35.91315 & 1.691775 & 0.03285 & 0.80775 & 0.14175 & 38.58728 \\
\hline & Forest & 5.687325 & 25.9722 & 0.081 & 0.6057 & 0.00315 & 32.34938 \\
\hline & Bush & 0.0036 & 0.024525 & 0.0468 & 0.0009 & & 0.075825 \\
\hline & Grass & 0.24165 & 0.25875 & 0.0009 & 1.7424 & 0.0045 & 2.2482 \\
\hline & Barren & 0.602325 & 0.0153 & & 0.04185 & 0.01395 & 0.673425 \\
\hline & & 42.44805 & 27.96255 & 0.16155 & 3.1986 & 0.16335 & 73.9341 \\
\hline
\end{tabular}

Source: LANDSHAT and Topo-sheet, 1990 and 2000 

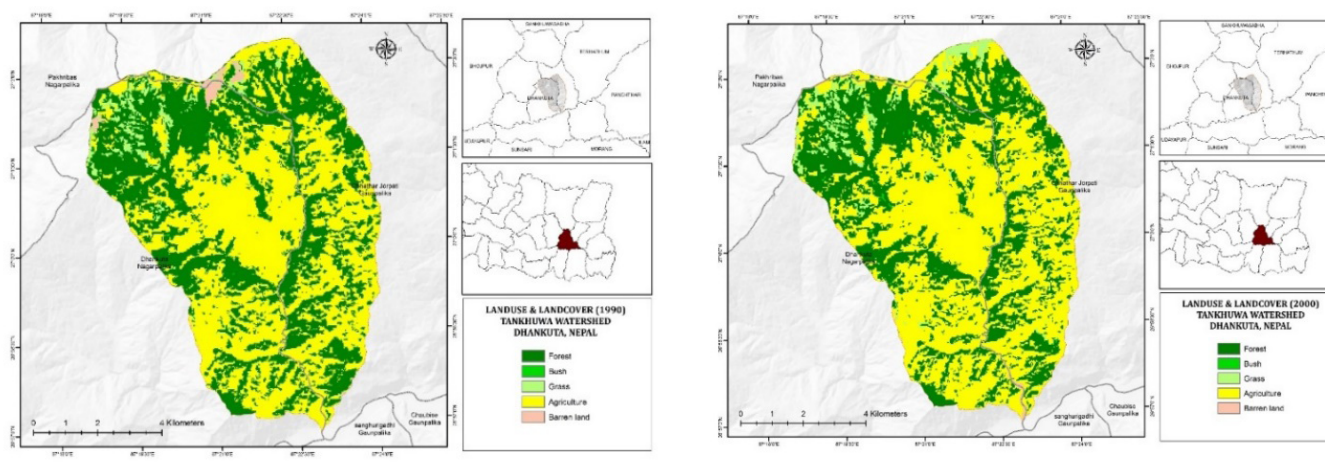

Figure 2 and 3: Land use and land cover map, 1990 and 2000

Table 1 shows the decadal changes in land use in the year of 1990 and 2010. The result indicates that lands are used for agriculture, forest, bushes, and grass, barren and built up. The figure indicates that agricultural land has been occupying the largest percentage share of the watershed area $(53.43 \%)$ and it was $52.20 \%$ in 1990 . It is followed by forest land in the second $(39.73 \% \mathrm{sq} . \mathrm{km}$.), grass and bush in the third (5.37\%) and it was $43.76 \%$ and $3.15 \%$ respectively for forest and grasses in 1990 . Other uses, such as river $(0.03 \%)$ and residential $(1.45 \%)$ are less significant as compared to agricultural and forest use lands (Fig. 2 and 3).

Table 2: Decadal land use and land cover change matrix analysis (2000 to 2010)

\begin{tabular}{|c|c|c|c|c|c|c|c|}
\hline \multirow{2}{*}{ Year } & \multirow{2}{*}{$\begin{array}{l}\text { Land use \& } \\
\text { Land Cover }\end{array}$} & \multicolumn{6}{|c|}{2010 (Area Sq. km) } \\
\hline & & Agriculture & Forest & Grass & Barren & Built up & \\
\hline \multirow{6}{*}{ 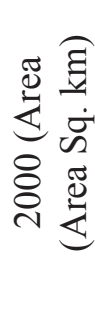 } & \multirow{6}{*}{$\begin{array}{l}\text { Agriculture } \\
\text { Forest } \\
\text { Bush } \\
\text { Grass } \\
\text { Barren }\end{array}$} & 34.776 & 4.501575 & 2.262825 & 0.024075 & 0.883575 & 42.44805 \\
\hline & & 3.3165 & 24.327 & 0.290925 & 0.000675 & 0.02745 & 27.96255 \\
\hline & & 0.0405 & 0.0864 & 0.03465 & 0 & 0 & 0.16155 \\
\hline & & 1.225575 & 0.4482 & 1.3797 & 0 & 0.145125 & 3.1986 \\
\hline & & 0.1422 & 0.0027 & 0.0036 & 0 & 0.01485 & 0.16335 \\
\hline & & 39.50078 & 29.36588 & 3.9717 & 0.02475 & 1.071 & 73.9341 \\
\hline
\end{tabular}

Source: LANDSHAT and Topo-sheet, 2000 and 2010

Table 2 shows the decadal changes in land use in the year of 2000 and 2010. The change result indicates that agricultural land has been occupying the $57.42 \%$ in the first, forest in the second (37.81\%), grasses $(4.33 \%)$ and barren and bushes $(0.22 \%$ for each). In 2010 the area covered the area of $1.45 \%$ of the total area (Fig. 4 and 5). 
Table 3: Decadal land use and land cover change matrix analysis (1990 to 2010)

\begin{tabular}{|c|c|c|c|c|c|c|c|}
\hline \multirow{2}{*}{ Year } & \multirow{2}{*}{$\begin{array}{l}\text { Land use \& } \\
\text { Land Cover }\end{array}$} & \multicolumn{6}{|c|}{2010 (Area Sq. km) } \\
\hline & & Agriculture & Forest & Bush & Grass & Barren & Total \\
\hline \multirow{6}{*}{ 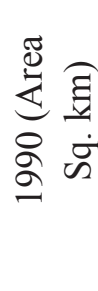 } & Agriculture & 32.8284 & 2.905875 & 1.9764 & 0.012375 & 0.864225 & 38.58728 \\
\hline & Forest & 5.42025 & 25.99268 & 0.8838 & 0.001125 & 0.051525 & 32.34938 \\
\hline & Bush & 0.015975 & 0.04635 & 0.0135 & 0 & 0 & 0.075825 \\
\hline & Grass & 0.663975 & 0.39735 & 1.044 & 0.0054 & 0.137475 & 2.2482 \\
\hline & Barren & 0.572175 & 0.023625 & 0.054 & 0.00585 & 0.017775 & 0.673425 \\
\hline & & 39.50078 & 29.36588 & 3.9717 & 0.02475 & 1.071 & 73.9341 \\
\hline
\end{tabular}

Source: LANDSHAT and Topo-sheet, 1990 and 2010
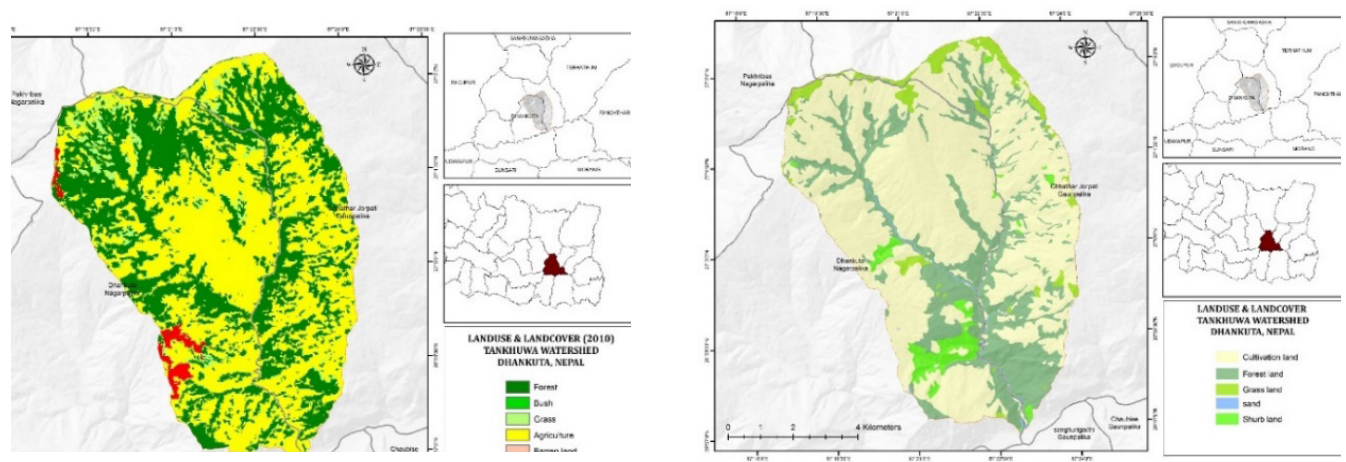

Figure 4 and 5: Land use and land cover map, 1990 and 2010

Table 3 shows the decadal changes in land use in the year of 1990 and 2010. The change results between 1990 and 2010 do not show the significant differences in land use change (Fig.4 and 5). The largest share of changes in the land use has occurred in forest and agricultural use in the year 1990 and about 5.93 and 5.22 percent for respectively. The area covered by grass and bushes decreases it is mainly due to the grasslands of the upper elevation zone largely converted into market centers, high-value commercial crops, potato and off-season vegetables for export. But this change does not appear to be the same rate in the whole watershed area. This variation depends on the amount of land distributed in different elevation zones. However, due to the lack of reliable data, this change has not been compared to the land use of 20 years ago.

\section{Factors to change}

The use of the land is highly dynamic in nature. It changes constantly in response to the impact of changing human attitude and actions (Zimmermann, 1951). For 
example, people and their sense of land have been the two fundamental elements of Tankhuwakhola watershed since the very beginning of human civilization. The reason is that the aboriginal/indigenous Kirati communities were far deep-rooted in this area and developed more rural and local material culture associated with hunting, pastoral and shifting cultivations. However, their customary land use no longer remained local, no longer fundamentally rural, and no longer character to material cultures. It is changing over the span of time. In this context, this paper argues that the historical, geographical, socio-cultural, economic, technological and institutional factors are more responsible for the changes of land use and land cover in the changing situations. They are discussed under the following headings:

Historical factors. The relations of land can be traced out to the historical geography of Tankhuwakhola watershed. The local people informed that the Athapahariya Rais have been considered as one of the most aboriginal/indigenous groups of Kirati people in this area. They claimed that they were a single authority of natural resources, including land in the Tankhuwakhola watershed. The land was prepared by the clearing the forest with the self-efforts of their forefathers. For a long time, the allocation of land, its control, conservation and uses have been legitimated by their lineage authority under the Kipat system. Due to the legitimacy of customary rights over the land, they have often known as owners of the land or Jimdar (Dahal, 1985). They had developed a customary land use system in various ways, such as agriculture, forestry, human settlement, grazing, water, hat-bazaar, cultural heritage, and others including cremation. Their deepest meaning, sense and attachments of land appears on the soil (Kham), home (Pang), forest, river and deities (Marga or Jimi).

It seems that there had been a lot of change in the use of land after the invasion of Limbu community in the Tankhuwakhola watershed. When the invasion of Limbu occupied the fertile land of the east of the watershed, the tribesmen had forced to cultivate on the steep slopes to the west of the same watershed. Now, the watershed resources had distributed into two parts which were using the only tribal people since ancient times. It seems that both groups have developed settled agriculture and pastoral civilization on both sides of the watershed area. Both groups had been involved in the land-based economic activities to meet the needs of a growing population. They had developed a systematic land use policy and resource use systems regarding their customary rights. It is known as Kipat system in this territory (Shrestha, 1995). For example, construction of the terraces on the steep slopes, regulation of water, flora, and fauna uses and management of grazing and agricultural lands. Their effort had developed more for a local, and a rural way of living intimated with nature, which is rooted in this watershed area. But this traditional land use system could not be maintained for long. The immigrants had brought about 
major changes over the indigenous land use systems. It is mainly due to different ethnic groups who migrated from different directions and times had attacked in this watershed to establish their authority over the land.

After the unification of Nepal, Dhankuta placed the main administrative Offices of Eastern Nepal. Meantime, the establishment of district-level government offices in 1961 also increased the importance of Dhankuta. This paper argues that there are some factors responsible for land use and land cover change. They are as follows: the establishment of Regional-level Offices, land acquisition for the Government Offices, the effort of KoshiHill Rural Development Program (KHARDEP), construction of Koshi highway and developmental activities. Other factors, such as land acquisition for army camps, police offices, instituting of lower level basic government service centers, schools-buildings, campus, hydropower, irrigation, urbanization, a new structure of local government, an effort of non-government organizations, investment in agribusiness, and an attraction of remittances for youths are also equally important to change.

\section{Geographical factors}

Terrain and elevation.There are various factors responsible for determining the land use and land cover change in the Tankhuwakhola watershed. In this area, enormous variations in the landscape can be observed from one place to another and characterized to the compression of climatic zones over short distances. The watershed lie between 295 to 2257 meters above sea level. This watershed is characterized by steep, rugged terrain. Only $5 \%$ of the land in this zone is suitable for cultivation but the local communities have used indigenous knowledge in the stock of land resources by the clearance of forest and carving terraces on the hill slopes for agricultural and livestock farming. The traditional land use of Tankhuwakhola watershed seems to have developed a layering of the system. The watershed area has classified into three elevation zones regarding to the District Agriculture Office's agro-ecological belts, such as lower or Besi (below 1000 m), middle or Kachhad (1000-1800 m) and upper or Lek (over 1800 m) (Table 4 and Figure 6).

Table 4: Terrain of Tankhuwakhola watershed

\begin{tabular}{c|l|c|c|c}
\hline SN & \multicolumn{1}{|c|}{ Elevation zones } & Height in $\mathrm{m}$ & Area in sq. Km & Percent \\
\hline 1 & Lower (Bensi) & Below 1000 & 23.23 & 31.43 \\
2 & Middle (Kachhad) & $1000-1800$ & 40.78 & 55.17 \\
3 & Upper (Lek) & 1800 above & 9.91 & 13.40 \\
\hline Total & & & 73.92 & 100 \\
\hline
\end{tabular}

Source: Topographic Map, 2010 
Table 4 shows the distribution patterns of the landscape terrain of the Tankhuwakhola watershed. The result indicates that the altitudinal extension of this watershed is ranging from 295-2257 $\mathrm{m}$ above sea level. The result indicates that the largest percent of the landscape lies in the middle elevation zone $(55.17 \%)$, it is followed by the lower elevation zone in the second (31.43\%) and lower in the upper elevation zone (13.40\%). With increasing access of road transportation upper elevation zone is linked with the larger, urban centers outside the hills has driven to a higher degree of land use and land cover change. For example, the lower elevation zone has dominated three crops, two crops in the middle and agro-pastoralism in the upper elevation zone in a year. Human settlements have generally concentrated in the elevation ranges 1000-1500 meters. The barter systems of potato and animal products of the upper elevation zone for cereal crops in the lower elevation zone were privileged for the fulfillment of local needs.

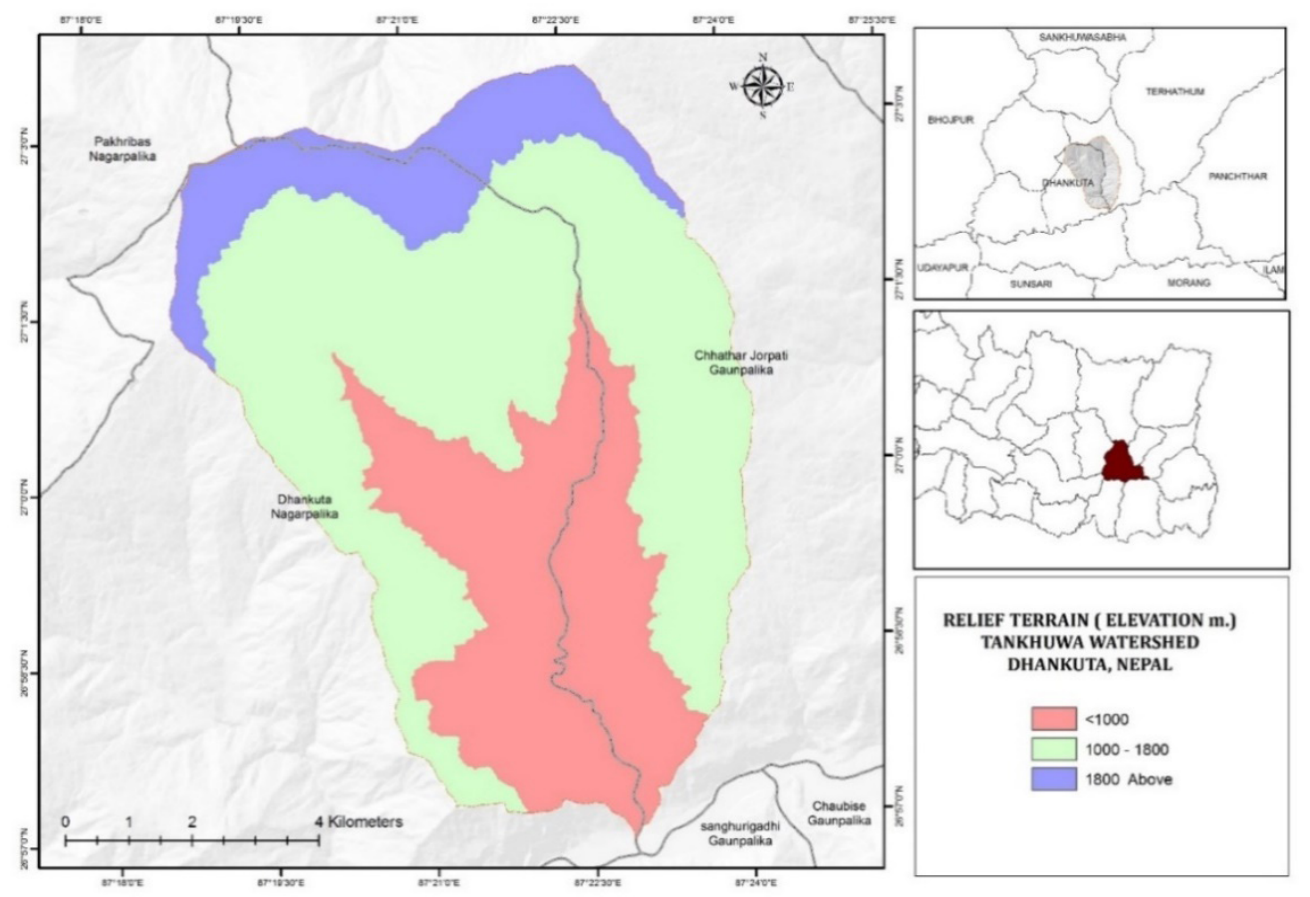

Figure 6: Terrain or elevation map

Slope. The slope is defined as the number of degrees the surface of the ground is inclined from the horizontal (Standford \& Moran, 1978, p. 253). The slope can be divided into different categories, such as gentle (less than $4^{\circ}$ ), moderate $\left(4^{\circ}\right.$ to $10^{\circ}$ ), and steep (over $10^{\circ}$ ) slopes. On the basis of this classification, the figure indicates that the largest part of 
the watershed area has consisted of steep to very steep slopes, even though some parts of the land comprise gentle to moderate slopes.

Table 5: Slope of Tankhuwakhola watershed

\begin{tabular}{c|c|c|c}
\hline SN & Slope in Degree & Area in sq. Km & Area in \% \\
\hline 1 & 0 to 10.12 & 4.00 & 5.41 \\
2 & 10.12 to 19.72 & 21.57 & 29.17 \\
3 & 19.72 to 26.99 & 25.47 & 34.45 \\
4 & 26.99 to 35.81 & 16.38 & 22.16 \\
5 & 35.81 to 66.18 & 6.51 & 8.80 \\
\hline Total & \multicolumn{2}{|c}{} \\
\hline
\end{tabular}

Source: Topo-sheet map, 2010

The slope gradients of this watershed have gradually increased from the south towards the north ranging from 0 to 66.18 degrees and divided into five classes (Table 5) and (Fig 7). However, it seems to have moderate to steep slopes which produces a greater local relief. It is mainly due to the slope which a vital factor is affecting to land use, soil erosion, the distribution of settlement and transportation in the watershed area.

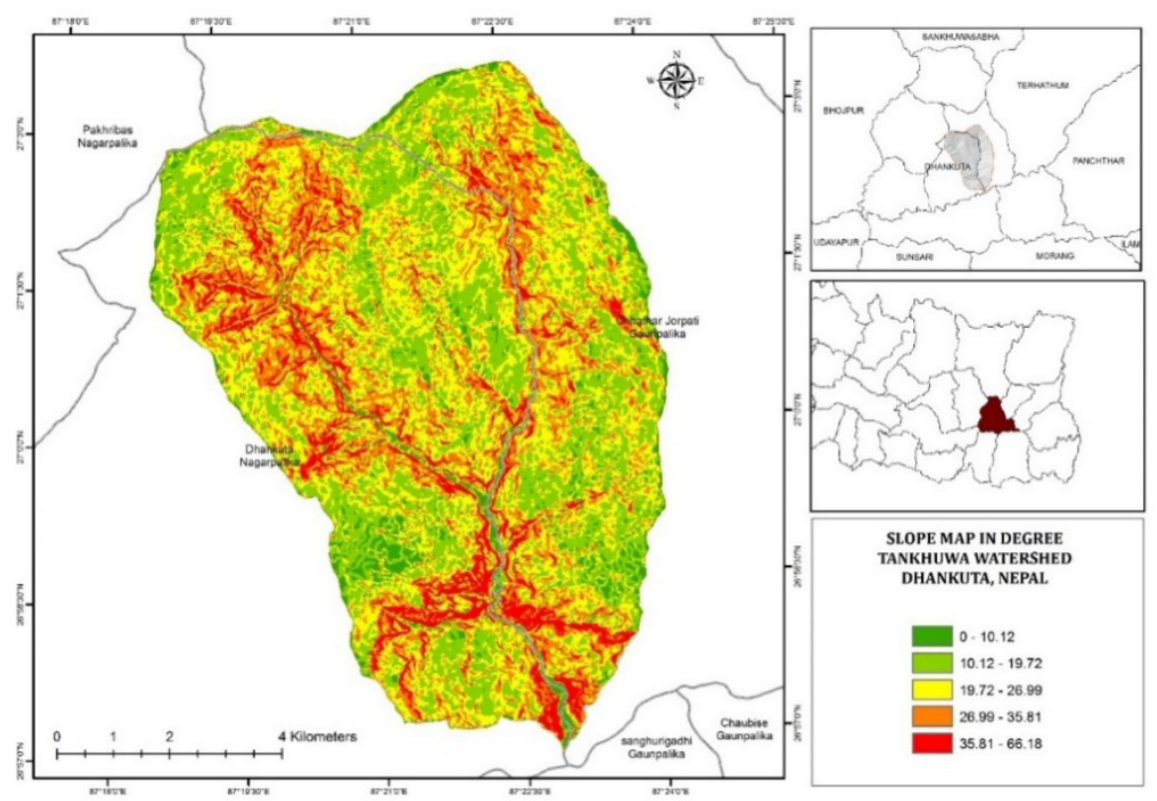

Figure 7: Slope map 
Table 5 shows the slope gradient of the Tankhuwakhola watershed area. The result indicates that the average slope gradient is $13.24^{\circ}$. However, the slope gradient varies from one category to another. For example, the largest percentage of land constituted slope gradient ranges from $19.72^{\circ}$ to $26.99^{\circ}(34.45 \%)$, it is followed by the gradient ranges $10.12^{\circ}$ to $19.72^{\circ}$ in the second $\left(29.17 \%\right.$ ) and least by the under $10^{\circ}(5.41 \%)$. FAO estimates that slope limits with soil depths adequate for hand-made terrace cultivation of 7 to 25 degree slopes (http://www.fao.org/3/ad083e/ad083e07.htm). The slope gradient above 10 degrees is characterized by the undulating terrain, covered with very thin, grayish to reddish brown, sandy and silty lateritic soil.

Sociocultural factors. The elements of the population, their activities and creations are considered the socio-cultural factors in the Tankhuwakhola watershed area. The population size has been considered as a referenced point of all aspects of land use and land cover change. The ethnic composition comprises 25583 persons of Chhetry, Bahun, Newar, Rais, Limbus, Magar, Tamang, and Dalits with average density 346.04 persons per sq. $\mathrm{km}$. The population distribution in relation to its physical environment remains a key factor to all economic activities and to create cultural environments, such as roads, houses, schools, cultural heritages and so on. The socio-cultural factors are also determined by the selection of crop species, food habits and drinking. For example, Athapahariya Rais are more subservient to grow rain-fed crops such as a kind of barley (Kagunu), millet (Pangdurkodo), dry-land paddy (Ghaiyadhan) and a kind of lentil (Gahat) offering to home god and local deities whereas wetland paddy by Chhetry and Bahun. Similarly, Chhetry and Bahun grow millet as a cash crop, whereas Kirati and Dalit communities grown for malt-liquor consumptions. It shows that the nature and tradition of local communities in terms of the user has been considered as a changing factor of land use. The result indicates that the relationship between local communities and land use and land cover change has largely been driven by increasing access of markets, rather than a deep-rooted rural economy. Malla \& Shrestha (1983) referred to Brock \& Webb (1978) that the requirements for various resources in the stage of social developments are equally relevant in the spatial analysis of land use in the watershed area.

Some places of historical interest in this watershed are located at the adjoining Dhankuta municipality and Chhathar-Jorpati Gaunpalika such as Thenapang and Dhankuta Gaunda. Temples, Gumbas, tea gardens and caves, waterfalls are also important tourist attractions. Mountain sight-seeing from the Trisule, Guranse and Jorpati, Athapahariya Rais, Magar and Tamang's popular folk cultures are also equally important to promote the tourism industry. However, it would require some policies towards investments in road, hotels and renovation of cultural heritage. 
Economic factors. The economic condition is reflected in response to its diverse geographical, socio-cultural and institutional aspects of the watershed area. Before the road construction, subsistence agriculture stays to be the basic mainstay where staple food crops were widely grown for household consumption. The regional agriculture inherent to the altitudes, slopes and quality of lands. For example, upstream-downstream exchanges of potato and livestock products were more common in the upper elevation zone is now largely grown off-season vegetables, potatoes, and high value cash crops for markets. The watershed can realize the advantages of site, soil and climate which have remained potential only since 1990s. The earthen road connects all settlements where jeeps, pickup vans and tractors provide services to local people. Indeed, porters were used to carry the load of farm products to sell in the periodic markets at Dhankuta, Hile and Sindhuwa. Nowadays, Koshi highway has made possible a high degree of land use and land cover change linked with Dharan, Itahari, Biratnagar and even Indian markets (Virgo \& Subba, 1996; and Khatiwada, 2014).

But little changes have been perceived in the middle and lower elevation zones. The factors of changes are increased in places where there are road access, investment in agribusiness (tea garden), innovation diffusion through GOs and NGOs, market demand in the upper and middle; and hydropower project, irrigation schemes and market demand for rice and livestock products in the lower elevation zone (Khatiwada, 2014). But these changes and the contemporary pattern of regional specialization are only noticed, especially in the upper elevation zone, but whole watershed is still dominated by a wider range of basic foodstuffs for local consumption. These changes have also effects on the spatial distribution of cropping patterns such as potato-vegetables-pigeon pea or fallow in the upper, maize-millet/mustard-wheat or vegetables or fallow in the middle and maize- millet/lentil-potato or fallow in the lower elevation zones for Bari. Rice-fallow/ wheat-rice is in the Khet. It shows that technological factors as well as people's awareness level, their practices and perceptions on land use and land value play an important role to show the direction and intensity of land use change. Similarly, government policy is also important. Therefore, factors of land use change should present in a comprehensive way.

\section{Conclusion}

There is a strong relationship between land use, the environment and the economy in Tankhuwakhola watershed. Typically, local economies are dependent on land and natural resource extraction from extremely diverse climate and topography. Land-use classes deal with agriculture, forest, water bodies and residential purposes. The first shelters had relatively little effect on the watershed resources. They had used the bulk 
of the local materials for food, timber, fuel wood, fodder and tools, and implements. The waves of transformation have begun to drive land use change after the late eighteenth century, when the Eastern Nepal is incorporated into Gorkha state. Paradoxically, much of the recent population growth, expansion of government offices, urbanization and development activities have driven the widespread transformation of land use in the watershed. The introduction of the market has changed into deep-rooted rural and the peasantry agricultural economy since the unification periods. As a result, contemporary economic and demographic changes yield a new horizon in land use and land cover that are marked with the introduction of a Panchayat political system in the 1960s.

Nowadays, the activities of local development through various User Groups such as road construction, irrigation, drinking water supply, watershed management, and forest conservation have also changed the land use and land cover in the watershed area. Similarly, the government policies regarding agricultural improvements have also helped to bring about changes in land use and land covers, such as pocket area, one village one product, and Prime Minister's Agriculture Modernization project.

\section{References}

Allan, N. J. (1986). Accessibility and altitudinal zonation models of mountains. Mountain Research and Development, 6 (3), pp.185-194.

Baron, J. S. (Eds.) (2002). Rocky mountain futures: an ecological perspective. Washington: Island Press.

Bencherifa A. (1988). Demography and cultural ecology of the Atlas Mountains of morocco: some new hypothesis. Mountain Research and Development 8 (4), pp. 309-313.

CBS (2013). Environment statistics of Nepal. Kathmandu: Central Bureau of Statistics (CBS).

Chorley, R. J. \& Haggett, P. (Eds.) (9175). Frontiers of geographical teaching. London: Methuen and Co Ltd.

Ellis, E. (2007). Land use and land cover change and climate change. Encyclopedia of Earth. https://web.archive.org/web/20070503192914/http://www. eoearth.org/article/Landuse_and_landcover_change.

FAO (1984). Land evaluation for forestry. Rome: Food and Agricultural Organization, FAO paper 48.

FAO \& UNEP (1999).The future of our land. Guidelines for integrated planning for sustainable management of land resources. Rome: Natural Resources Management and Environment Department. 
HMG of Nepal (1964). Land rules: Nepal gazette (22 Nov. 1964). Kathmandu: HMG of Nepal.

Khatiwada, S. P. (2010). Continuity and change of livelihood activities in the Tankhuwakhola watershed, eastern hills, Nepal. In P. K. Pradhan, B. P. Subedi and N. R. Khanal (Eds.), Environment, livelihood and microenterprises. Kathmandu: Central Department of Geography, pp. 121-134.

(2014). Spatial patterns of the agro-based livelihoods of the communities of the Tankhuwakhola watershed, eastern hills, Nepal. Kathmandu: Unpublished PhD Thesis, Deans Office, Faculty of Humanity and Social Sciences

Malla, U. M. \& Shrestha, C. B. (1983). Environmental resource management in Nepal. Kathmandu: University Press.

MoAD, (2013). Statistical information on Nepalese agriculture (2012/2013). Kathmandu: Government of Nepal, Ministry of Agricultural Development Agri-Business Promotion and Statistics Division.

Price, M. F., Byers, A. C., Friend, D. A., Kohler, T. \& Price, L. W. (Eds.) (2013). Mountain geography: Physical and human dimensions. California: University of California Press.

Sharma, C. K. (1978). Natural resource of Nepal. Kathmandu: Sangeeta Sharma.

Shrestha, S. K. (1995). Limbuwan ko aitihasika dhyan. Lalitpur: Kirat Prakashan and Abhilekhan Kendra.

Standford, H. Q., \& Moran, W. (1978). Geography: A study of its physical elements. New York: oxford University Press.

Travis, W. R., Theobald, D. M. \& Fagre, D. B. (2002). Transforming the Rockies: Human forces, settlement patterns, and ecosystem effects. In Baron, J. S. (Eds.) 2002. Rocky mountain futures: an ecological perspective. Washington: Island Press, pp. 1-24.

Turner, B.L., Skole, D., Sanderson, S., Fischer, G., Fresco, L. \& Leemans, R. (1995). Land-use and land-cover change science/research plan. IGBP Report No. 35 \& HOP Report No. 7.

Virgo, K. J. \& Subba, K. J. (1994). Land use change between 1978 and 1990 in Dhankuta district, Koshi hills, Eastern Nepal. Mountain Research and Development, 14 (2), pp. 159-170.

Zimmermann, E. W. (1951). World resources and industries: A functional appraisal of the availability of agricultural and industrial materials. New York: Harper and Brothers, publishers. 